\begin{tabular}{l}
\hline Jurnal Scripta Teologi dan Pelayanan Kontekstual \\
ISSN \\
ISSN \\
Http://ejournal.stte.ac.id \\
Vol.4, No.1, pp. 69-84, 2019
\end{tabular}

\title{
Tinjauan Alkitabiah Terhadap Falsafah Jawa "Ing Ngarsa Sung Tuladha, Ing Madya Mangun Karsa, Tut Wuri Handayani"
}

Suharta

STT Ebenhaezer Tanjung Enim, Imsuharta.te@gmail.com

\section{INFO ARTIKEL}

Sejarah Artikel:

Diterima : 04 Mei 2019

Direvisi : 11 Mei 2019

Disetujui: 18 Mei 2019

Dipublikasi: 28 Mei

2019

Kata Kunci:

Tinjauan, Alkitabiah, Falsafah.

Keywords:

keyword one, keyword two, keyword three.

\section{ABSTRAK}

Orang Jawa memiliki kehidupan yang erat dengan falsafah. Falsafah tersebut menjadi pedoman bagi kehidupan mereka, yang terus diajarkan dan dipertahankan secara turun-temurun. Orang Jawa masih menerapkan falsafahnya sampai saat ini karena bagi orang Jawa, falsafah Jawa memiliki nilai-nilai kehidupan yang baik. Selain itu yang menjadi alasan bagi orang Jawa untuk tetap menerapkan falsafah maupun tradisinya adalah karena mereka mau mempertahankan falsafah supaya tidak hilang. Orang Jawa akan merasa bangga jika dapat mempertahankan nilai-nilai kehidupan yang telah diajarkan oleh para leluhurnya. Namun bukan hanya orang Jawa pada umumnya yang menerapkan falsafah Jawa, tetapi orang Kristen Jawa juga masih menerapkan, bahkan mempersamakan falsafah Jawa dengan Firman Tuhan. Seharusnya orang Kristen tidak melakukannya, namun itu yang terjadi. Mereka mengetahui bahwa sebagai orang Kristen harus menerapkan Firman Tuhan, namun jemaat juga tidak mau melupakan falsafahnya. Namun dan tidak semua falsafah Jawa bernilai baik. Apalagi jika diterapkan oleh orang Kristen. Namun tidak juga semua falsafah Jawa bertentangan dengan Firman Tuhan. Untuk menyelesaikan permasalahan di atas maka penulis mengadakan penelitian dengan menggunakan pendekatan kualitatif dan menggunakan metode deskriptif dengan paradigma Bibliologis. Penulis menggunakan metode tersebut karena metode tersebut yang sesuai dengan permasalahan yang diteliti oleh penulis. Penulis mau meninjau falsafah Jawa "Ing Ngarsa Sung Tuladha, Ing Madya Mangun Karsa, Tut Wuri handayani" berdasarkan Alkitab, supaya dapat diketahui apakah falsafah tersebut bertentangan dengan Firman Tuhan atau tidak. Dan supaya jemaat tahu falsafah yang harus diterapkan. Untuk memperoleh data yang lebih akurat maka penulis juga melakukan survei lapangan dengan melakukan wawancara kepada para informan.

\footnotetext{
ABSTRACT

Javanese have a close life with philosophy. This philosophy became a guideline for their lives, which continued to be taught and maintained for generations. Javanese people still apply their philosophy to this day because for Javanese people, Javanese philosophy has good life values.
} 
Besides that, the reason for Javanese people to continue to apply philosophy and tradition is because they want to maintain philosophy so that it does not disappear. Javanese people will feel proud if they can maintain the values of life taught by their ancestors. But it is not only Javanese who generally apply Javanese philosophy, but Javanese Christians also still apply, even equating Javanese philosophy with the Word of God. Christians should not do it, but that is what happened. They know that as Christians they must apply God's Word, but the congregation also does not want to forget its philosophy. However and not all Javanese philosophy is of good value. Especially if applied by Christians. But not all Javanese philosophies contradict the Word of God. To solve the above problems, the authors conducted research using a qualitative approach and using descriptive methods with a bibliological paradigm. The author uses the method because the method is in accordance with the problems studied by the author. The author wants to review the Javanese philosophy "Ing Ngarsa Sung Tuladha, Ing Madya Mangun Karsa, Tut Wuri handayani" based on the Bible, so that it can be known whether the philosophy is contrary to God's Word or not. And so the congregation knows the philosophy that must be applied. To obtain more accurate data, the authors also conducted a field survey by interviewing informants.

\section{Pendahuluan}

Dalam kehidupan sehari hari orang Jawa pada umumnya erat dengan falsafah. Dalam menyampaikan sesuatu biasanya mereka menggunakan wangsalan maupun perumpaman lainnya. Oleh karena itu berbicara mengenai falsafah Jawa adalah sesuatu hal yang menarik karena, masyarakat Jawa pada umumnya senang berbicara mengenai warisan budaya para leluhurnya. Masyarakat Jawa menjadikan falsafah sebagai pedoman kehidupan mereka. Mereka hidup berdasarkan falsafah yang masih kental melekat pada diri mereka. Mereka akan merasa bangga jika dapat mempertahankan atau memelihara hal-hal baik atau prinsip-prinsip hidup leluhur dapat di lakukan.

Falsafah yang cukup terkenal dan menjadi logo dalam pendidikan di Indonesia adalah Tut Wuri Handayani, yang sebenarnya adalah serangkaian dengan Ing Ngarsa Sung Tuladha, Ing Madya Mangun Karsa, Tut Wuri Handayani. Falsafah tersebut berbicara mengenai kepemimpinan. Falsafah lain yang masih dianut sampai saat ini diantaranya yaitu "Alon-alon waton kelakon", ada juga "Mangan Ora Mangan Ngumpul" yang artinya makan tidak makanyang penting berkumpul, dalam pernyataan ini yang terpenting bagi orang Jawa adalah kebersamaan. Pada dasarnya tradisi maupun falsafah kehidupan orang Jawa dijadikan acuan bagi masyarakat Jawa untuk bertindak. Karena masyarakat Jawa akan merasa senang jika dapat terus mempertahankan falsafahnya tersebut. Bahkan bukan hanya masyarakat Jawa pada umumnya, namun orang-orang Kristen Jawa pada kususnya masih menganut falsafah tersebut.

Niel Mulder dalam bukunya yang berjudul Pribadi dan Masyarakat di Jawa berpendapat bahwa "Falsafah Jawa tersebut pada dasarnya adalah Kejawen. Kejawen bukanlah suatu kategori keagamaan, tetapi menunjukan pada suatu etika dan gaya hidup yang didasari oleh pemikiran Javanisme". Javanisme adalah suatu tindakan dan pikiran yang berasal dari masyarakat Jawa sendiri, yang sampai sekarang masih diterapkan. 
Akan tetapi yang menerapkan bukan hanya orang Jawa pada umumnya tetapi juga orang Jawa yang beragama Kristen dan Katolik, karena itu ada sebutan Kristen abangan dan Katolik Abangan. Abangan berarti beriman namun tidak beriman dalam arti sesungguhnya. Mereka mengku beragama tertentu namun kenyatannya tradisi Jawa lebih di utamakan dari pada ajaran agama yang diakuinya. Contoh bahwa mereka menerapkan tradisi kejawen adalah Resik Kubur, orang Kristen masih melakukan tradisi Resik Kubur pada saat akanmenikahkan anaknya sebagai ungkapan terimakasih kepada leluhur dan ungkapan rasa hormatnya kepada mereka. Hal itu bagi masyarakat Jawa merupakan hal yang biasa, karena bagi orang Jawa hal itu merupakan wujud bahwa mereka menghormati orang tua atau leluhur mereka yang sudah meninggal.

Seorang hamba Tuhan berinisial A berpendapat bahwa"falsafah dalam kehidupan masyarakat Jawa adalah hal yang lumrah diterapkan karena hal tersebut adalah baik, contoh yang ia sebutkan adalah falsafah Jawa yang berkenaan dengan keteladanan, motifasi dan kekuatan, jadi dalam hubungan antara hamba Tuhan dan jemaat hendaknya dapat menggambarkan "Ing Ngarsa Sung Tuladha", yaitu sebagai hamba Tuhan yang memimpin haruslah menjadi teladan, Ing Madya Mangun Karsa, selain memberi teladan juga harus memberikan motivasi, dan Tut Wuri Handayani, yaitu jemaat dari belakang memberi kekuatan atau dorongan. Sehingga dengan adanya penerapan tersebut diharapkan akan terjadi hubungan yang harmonis antara hamba Tuhan dan jemaat sehingga pelayanan akan berjalan dengan lancar".

Orang Kristen adalah orang yang seharusny memiliki kehidupan yang berbeda dengan yang lainnya. Orang yang mengaku percaya kepada Kristus, seharusnya kehidupannya berubah, memiliki pola pikir yang benar dan berpikir yang benar tentang kebenaran. Seorang hamba Tuhan berinisial S selalu mengatakan kepada anak-anak rohaninya bahwa seorang anak Tuhan atau orang Kristen harus selalu memiliki gaya hidup yang berbeda dengan lainnya. Orang percaya seharusnya beribadah hanya kepada Allah, karena ibadah bertujuan untuk bersekutu dengan Allah sang pencipta. Allah menciptakan manusia untuk menjadi sekutu-Nya, sekalipun dosa merusak hubungan manusia dengan Allah namun Allah senantiasa mencari manusia. Allah tidak akan membiarkan manusia hidup terus-menerus dalam dosa. Karena itu ia memberikan jalan keluar agar manusia dapat kembali kepada Allah.

Oleh anugerahnya manusia di beri jalan untuk beribadah, maka ibadah menjadi hal penting yang harus di lakukan oleh orang Kristen. Ibadah bukan hanya sekedar hadir di gereja tetapi ibadah merupakan sikap penyembahan kepada Allah secara terus-menerus. Hidup orang percaya yang telah diubahkan oleh Kristus, seharusnya akan mengubah hidup orang lain, pelipat gandaan ini adalah bukti nyata perubahan terjadi pada diri seseorang.

Perubahan yang terjadi pada diri seseorang aka dapat dilihat oleh orang lain. Perubahan yang di maksud di sini adalah perubahan yang menyeluruh dalam tiap aspek kehidupan orang Kristen. Pada saat seseorang menyatakan percaya kepada Allah, hal itu bukan berarti hanya percaya kepada kebenaran tertentu mengenai Allah tetapi jauh dari pada itu, orang Kristen harus hidup dalam suatu hubungan perjanjian dengan Allah dalam skepercayaan dan keutuhan. Hubungan ini terjadi karena prakarsa Allah untuk memperbaiki hubunganNya dengan manusia yang telah rusak karena dosa. 
Orang Kristen bukan hanya perlu memiliki pola pikir yang benar mengenai kebenaran Kristus namun orang Kristen harus memiliki kehidupan doa yang bukan sekedar rutinitas, namun memenuhi kehidupannya dengan doa. Karena itu doa merupakan suatu kebutuhan manusia, bukan suatu beban yang harus dilakukan karena terpaksa. Doa adalah disiplin rohani yang paling central karena doa merupakan hak istimewa anak Allah, berdoa juga merupakan nafas hidup orang Kristen, jika orang Kristen tidak berdoa sama saja dengan tidak bernafas.

Dalam sebuah relasi memerlukan sebuah komunikasi yang baik, demikian juga antara manusia dengan Allah memerlukan sebuah komunikasi yaitu dengan doa. Dalam doa manusia, berkomunikasi dengan Allahdengan komunikasi yang baik maka akan menimbulkan pengenalan yang benar akan Kristus. Intensitas dan kesungguhan dalam berdoa sangatlah penting khususnya jika seseorang sedang mengharapkan jalan keluar atau sebuah terobosan tertentu dalam hidupnya. Di dalam doa orang Kristen dapat menemukan damai sejahtera dan kekuatan akan permasalahan yang sedang di hadapi.

Orang percaya juga harus hidup dalam FirmanNya, karena manusia mengenal Allah melalui firmanNya dan doa. Melalui firmanNya Allah menyatakan diriNya kepada manusia berdosa. 2 Timotius 3:15, menyatakan bahwa pengenalan akan kitab suci telah memberikan hikmat kepada Timotius untuk menuntunnya kepada keselamatan di Dalam Yesus. Oleh FirmanNya manusia dapat mengenal keselamatan di Dalam Kristus dan di dalam FirmanNya orang Kristen dapat mengerti kehendak Allah dalam hidupnya. Sehingga manusia dapat hidup berkenan kepada Allah. Orang Kristen harus memiliki iman yang benar kepada Allah. Iman berarti penyerahan tanpa curiga dan bergantung sepenuhnya tanpa curiga dan bergantung sepenuhnya kepada yang dipercayai. Kadang iman dikaitkan dengan kesadaran akan "satu yang melampaui kekutan manusia, atau bisa juga dikatakan "pusat dari segala sesuatu". Yohanes 5:24 menyatakan bahwa kehidupan orang yang memiliki iman kepada Kristus yang sudah mengenal dan menerima jalan keselamatan dan jaminan keselamatan adalah kehidupan baru yang berbalik arah, yang telah berpindah dari maut kedalam hidup. Jeremia Rim menjelaskan dalam bukunya bahwa Paulus menjelaskan di dalam surat Kolose 1:21-23, bahwa yang harus dilakukan oleh orang percaya adalah berpegang teguh pada iman, karena Yesus telah menderita jasmani untuk mendamaikan manusia dengan Allah, jika manusia ada di pihak Allah maka ia menang. Karena itu orang Kristen haruslah bertekun di dalam iman. Selain iman percaya yang harus di miliki orang Kristen juga harus menjadikanKristus sebagai pusat hidupnya Pernyataan ini secara tidak di sadari sebenarnya ada dalam pengakuan iman yang seringkali di ucapkan oleh orang Kristen. Pernyataan ini adalah pusat dari susunan pengakuan iman Rasuli. Menjadikan Kristus sebagai pusat hidup berarti menjadikan Kristus pusat dari seluruh kehidupan kita.

Rasul Paulus menjelaskan kepada jemaat di Roma, bahwa orang Kristen juga mengakui otoritas Kristus dalam hidupnya. Karena manusia lama yang telah berubah menjadi manusia baru. Saat orang percaya mengakui bahwa Yesus adalah Tuhan maka ia siap menerima setiap hal yang berkaitan dengan keputusannya tersebut. Mengakui Yesus Sebagai yang berotoritas dalam kehidupannya adalah tunduk kepada kehendak Kristus dalam segala hal. Sebagai orang percaya seharusnya hidup dalam kebenaran Tuhan, serta senantiasa hidup berpusat kepada Kristus. Selain semua kebenaran tersebut orang percaya harus mengakui otoritas Kristus dalam hidupnya, karena 
hidupnya bukan milik dia sendiri melainkan milik Kristus. Sehingga harus hidup sesuai dengan kebenaran Kristus, kebenaran dan keadilan Allah harus menjadi harus menjadi prinsip hidup orang percaya. Hidup sesuai dengan kebenaran firman Allah haruslah menjadi hal yang otomatis yang dilakukan oleh orang percaya bersama dengan karya Roh Kudus dalam kehidupannya.

\section{Metode Penelitian}

Dalam penulisan ini penulis menggunakan metode deskriftif-bibliologis. Metode deskriftif adalah suatu metode penelitian yang meneliti sekelompok manusia, suatu objek, suatu kondisi, suatu sistem pemikiran ataupun suatu kilas peristiwa masa sekarang.

Ada pun tujuan penelitian ini adalah untuk memuat deskripsi, gambaran atau lukisan secara sistematis, faktual dan akurat mengenai fakta-fakta, sifat-sifat serta hubungan antar fenomena yang diteliti.

Selain itu tujuan dari penelitian ini untuk mengumpulkan data, gambaran, penegasan suatu konteks atau gejala serta sesuatu pertanyaan hubungan dengan status subjek penelitian saat ini. Pengumpulan data dilakukan dengan cara penelitian, menganalisis literatur dan untuk mendapatkan data yang lebih lengkap.

\section{Hasil Dan Pembahasan \\ Hakikat Dan Tinjauan Alkitabiah Terhadap Falsafah Jawa "Ing Ngarsa Sung Tuladha, Ing Madya Mangun Karsa, Tut Wuri Handayani”}

Pdt. Eka Darmaputra menuliskan dalam bukunya yang berjudul kepemimpinan dalam persepektif Alkitab menyatakan demikian: "Seorang pemimpin yang baik harus mau menjadi pengikut yang baik, seorang pemimpin yang baik harus terlebih dahulu lulus sebagai hamba yang baik". Seorang pemimpin yang baik adalah mereka yang telah taat melakukan dan setia dalam perkara sederhana yang telah dipercayakan. Karena seseorang yang setia dalam perkara yang sederhana yang Tuhan percayakan, maka Tuhan akan mempercayakan hal yang jauh lebih besar untuk orang tersebut.

Seorang pemimpin idealnya adalah seseorang yang dapat diteladani sikap dan tindakannya, senantiasa berada di tengah-tengah orang yang dipimpinnya, dan senantiasa memberikan motivasi atau dorongan kepada orang-orang yang dipimpinnya. Seorang pemimpin bukan hanya menuntut orang yang dipimpinnya untuk melakukan apa yang menjadi kehendaknya, namun ia sudah terlebih dahulu untuk memberikan contoh dari setiap apa yang ia kehendaki pada bawahannya.

Richard Clinton dalam bukunya yang berjudul "Memulai Dengan Baik" berkata: "Seorang pemimpin seharusnya adalah orang yang memiliki integritas. Karena dengan integritas yang dimiliki oleh seorang pemimpin akan menjadikan dia pemimpin yang disegani oleh bawahannya". Karena integritas adalah fondasi dari karakter kesalehan.

John C Maxwell mengatakan: integritas adalah "kualitas atau keadaan utuh yang dilakukan." Dengan integritas membuat orang yang dipimpin berkeinginan untuk mengikuti arahan sang pemimpin. Guru bukan hanya sekedar mengajar di kelas namun kesuksesan seorang guru adalah ketika para murid yang diajar dapat mendengarkan dan melakukan pengajarannya. Mendidik bukan hanya sekedar 
memberikan pengajaran, tetapi memberi suri teladan adalah hal yang penting. Dari keleladanan sang guru murid dapat belajar banyak hal. Dengan teladan yang diberikan oleh gurunya akan mempermudah sang murid dalam belajar, serta memahami pengajaran gurunya.

\section{Falsafah Dan Kehidupan Orang Jawa}

Kehidupan orang Jawa erat dengan falsafah, maka bukan hal yang baru jika kalangan orang Jawa membicarakan falsafah yang berkenaan dengan keteladanan. Karena itu, falsafah bukanlah hal yang asing bagi orang Jawa. Karena dalam berbicara sehari-hari mereka sering menggunakannya.Menurut Daniel Goleman dalam bukunya: Falsafah Jawa inilah yang mendorong, tindakan, dan perasaan berbeda dengan lainnya. Seperti falsafah Jawa "Ing Ngarsa Sung Tuladha, Ing Madya Mangun Karsa, Tut Wuri Handayani" falsafah ini sudah sangat terkenal di sekolah. Bahkan falsafah ini menjadi acuan bagi para guru di Indonesia dalam melakukan tugasnya sebagai seorang guru. Falsafah yang cukup terkenal dan menjadi lambang dalam logo pendidikan di Indonesia adalah "Tut Wuri Handayani," namun falsafah tersebut seyogianya dilengkapi dengan Ing Ngarsa Sung Tuladha, Ing Madya Mangun Karsa. Falsafah ini cukup terkenal dan orang Kristen juga mengetahui falsafah ini sehingga mereka juga mengikutinya.

\section{Ki Hadjar Dewantara Tokoh Pencetus Falsafah}

Tokoh pencetus falsafah Jawa "Ing Ngarsa Sung Tuladha, Ing MadyaMangun Karsa, Tut Wuri Handayani” adalah Ki Hadjar Dewantara. Mirnawati dalam bukunya menuliskan bahwa:“Ki Hadjar Dewantaraadalah seorang bangsawan yang berasal dari lingkungan Keraton Yogyakarta. Ki Hajar Dewantara lahir di Yogyakarta, 2 Mei 1889 dan meninggal di usia 69 tahun di Yogyakarta, tepatnya pada tanggal 26 April 1959".

\section{Latar Belakang Falsafah Jawa “Ing Ngarsa Sung Tuladha, Ing Madya Mangun Karsa, Tut Wuri Handayani"}

Pendidikan merupakan hal yang penting yang perlu di laksanakan oleh suatu bangsa. Karena pendidikan akan menunjang majunya suatu bangsa, bangsa yang maju tentu didukung dengan pendidikan warganya yang maju. Dengan pendidikan yang baik maka akan dapat mengubah kehidupan seseorang. Mengubah cara berfikirnya serta mengubah tingkah laku seseorang. Pendidikan penting bagi semua lapisan masyarakat, pendidikan pertama yang didapat oleh seseorang adalah dalam lingkungan keluaga. Karena itu keluarga merupakan dasar pendidikan bagi seseorang karena di dalam keluargalah seseorang pertama kali mendapat pendidikan.

Sebagai seorang pendidik seharusnya bukan hanya pandai mengajarkan pada para muridnya namun seharusnya para pendidik juga menjadi teladan bagi mereka. Karena keteladanan merupakan hal yang penting yang harus dilakukan oleh seorang guru, seorang mentor, maupun orang tua. Karena dalam mendidik merupakan kesempatan untuk dapat mengubah hidup seseorang menjadi lebih baik.

Namun banyak kenyataan didapati bahwa para pendidik tidak menjadi teladan, contohny adalah berita yang disiarkan oleh televisi pada 8 juni 2018 ada seorang guru justru yang berlaku tidak senonoh dengan murid yang diajarnya. Bukan hanya hal 
tersebut namun penulis juga pernah melihat seorang guru berinisial $M$, yang menghukum anak didiknya dengan memukul kakinya dengan penggaris kayu.

Ki hadjar Dewantara melihat bahwa pendidikan di Barat sarat dengan hukuman. Beliau melihat jika sistem pendidikan semacam itu di terapkan di Indonesia tidaklah tepat. Pendidikan negara Belanda mengarahkan anak didiknya setelah lulus menjadi budak belanda, yaitu dengan bekerja pada pemerintahan Belanda. Karena bangsa Indonesia berbeda dengan dunia Barat, dengan melihat kenyataan tersebut maka Ki Hadjar Dewantara mencetuskan falsafahnya.

\section{Tujuan Falsafah Jawa “Ing Ngarsa Sung Tuladha, Ing Madya Mangun Karsa, Tut Wuri Handayani"}

Tujuan Ki hadjar Dewantara mencetuskan falsafahnya adalah supaya, guru-guru yang mengajar di Indonesia menjadi teladan bagi murid-muridnya. Bukan hanya mengajar tapi dapat menjadi teladan dan kebanggaan bagi murid-murid yang diajarnya. Guru adalah seseorangyang kehidupannya menjadi acuan bagi para muridmurid yang diajarnya. Jika berbicara mengenai guru, orang Jawa mengartikan bahwa guru adalah seseorang yang digugulan ditiru. Digugu berarti didengar atau diindahkan perkataannya, ditiru berarti di ikuti tindakannya. Menjadi seorang guru hendaknya menjadi orang yang didengar nasehatnya tapi juga di ikuti tindakannya.Rakhmawan menuliskan bahwa: "Ki Hadjar Dewantara memiliki cita-cita bahwa guru harusbisa menjadi teladan dalam kehidupannya". Sehingga murid melihat seorang guru bukan sebagai sosok yang harus di takuti namun disegani.

Jika guru menjadi teladan bagi murid-muridnya, maka akan mudah murid untuk dapat memahami pelajaran yang ada. Menjadi guru bukan hanya sebagai pengajar yang hanya mengajar di dalam ruang kelas, namun guru harus menjadi teladan dalam kehidupan. Di tengah tengah kesibukan harus bisa memberikan motivasi, dan dari belakang harus bisa memberikan kekuatan. Seorang murid biasanya akan selalu ingat akan apa yang dilakukan oleh gurunya. Jika sang guru menjadi teladan bagi para murinya maka sang murid akan ingat terus hal tersebut sampai ia dewasa nanti. Jika sang guru melakukan hal buruk terhadap muridnya maka muridnya juga akan terus mengingat perlakukannya tersebut. Karena itu menjadi guru bukanlah hal yang mudah.

\section{Tinjauan Alkitabiah Terhadap Falsafah Jawa "Ing Ngarsa Sung Tuladha, Ing Madya Mangunkarsa, Tut Wuri Handayani"}

Falsafah Jawa "Ing Ngarsa Sung Tuladha, Ing Madya Mangun Karsa, Tut Wuri Handayani," mengandung prinsip-prinsip kebenaran yang telah sumbangkan di sekolah sekolah yang ada di Indonesia. Yang paling terkenal dan menjadi logo dunia pendidikan di Indonesia adalah Tut Wuri Handayani.Seorang guru PKN berinisial I berpendapat bahwa falsafah kepemimpinan Ki Hadjar Dewantara harus dipahami oleh setiap orang yang menjadi pengajar, sebagai acuan untuk hidupnya sebagai seorang pengajar. Karena falsafah kepemimpinan Ki hadjar Dewantara, menurutnya sangat tepat jika diterapkan oleh para pemimpin maupun guru-guru yang ada di Indonesia. Karena seorang murid bukan hanya membutuhkan materi dalam pembelajaran, namun juga membutuhkan sebuah keteladanan. Karena guru atau pemimpin para murid-muridnya maka teladan akan sangat mempengaruhi murid-murid yang diajarnya. 
Orang Kristen Jawa pada umumnya juga mengenal falsafah tersebut, dan seringkali mereka juga mengetahuinya dan tanpa sadar juga menerapkannya.John R.W. Stott dalam bukunya menuliskan bahwa: "Sebagai orang Kristen yang seharusnya menjadi acuan sebuah kebenaran adalah Alkitab.Karena kebenaran Alkitab adalah mutlak yang seharusnya menjadi tolok ukur bagi hidupnya.Orang yang menjadikan kebenaranAlkitab sebagai tolok ukur hidupnya pada akhirnya akan memiliki karakter Kristus dan hidupnya memuliakan Kristus". Falsafah Jawa memang baik, namun seharusnya sebagai orang percaya Firman Tuhan harus lebih di utamakan dan ditaati.

\section{Perjanjian Lama Nehemia 1:4 dan 6}

Dalam Nehemia 1:4-10, ini adalah doa Nehemia sebagai respon dengan apa yang telah ia dengar dari Hanani mengenai keadaan Yerusalem. "Maka aku berdoa kepada Allah semesta langit", ini adalah doa yang singkat yang dipanjatkan secara diam-diam oleh Nehemia dan di dukung dengan doa puasa selama beberapa minggu. Hal ini menghasilkan perubahan politik kerajaan yang termasuk paling mengejutkan disepanjang sejarah.

Ketika kudengar, kata dengardalam bahasa aslinya adalah menggunakan kata shama, dalam bahasa Inggris diterjemahkan to hear, listen to, obey, to hear with attention or interestdi sini menunjukan bahwa Nehemia bukan hanya mendengar saja namun ia jugamemperhatikan dan berempati dengan apa yang ia dengar. Hal ini sangat berbeda dengan seseorang yang hanya mendengar tanpa memiliki empati akan apa yang di dengarnya. la sedih, menangis, dan berkabung selama beberapa hari.Ini bukan hanya suatu kesedihan yang sekedar bersifat nasional, tetapi bersifat rohani. Sedih karena berita yang ia dengar sangat membuat hatinya terluka.

Orang sering mengungkapkan kesedihan hatinya yang mendalam dengan duduk sambil menangis dan dengan berpuasa. Hal tersebut menunjukan bahwa Nehemia sungguh sangat berduka dengan berita buruk yang di dengarnya.

Kabar buruk ini ada dalam ayat 3, dan meliputi 2 hal, yaitu:

- Orang-orang di Yerusalem ada dalam kesukaran besar dan dalam keadaan tercela. Ini merupakan suatu keadaan yang menyedihkan.

- Tembok Yerusalem terbongkar. Ada 2 pandangan tentang hal ini: pandangan pertama: Hal ini baru saja terjadi di antara Ezra dan Nehemi, Ezra merupakan nabi yang sejaman dengan Nehemia, Ezra yang melakukan pembaharuan bait suci sedangkan Nehemia melakukan pembangunan kota dan tembok di Yerusalem. Jadi Ezra melakukan pembangunan rohani sedangkan Nehemia melakukan pemabagunan secara fisik namun semuanya samamelakukan hal yang penting bagi umat Allah. Pandangan ke dua, hal ini terjadi pada jaman Nebukadnezar dan sejak saat itu tidak pernah dipulihkan (Penafsiran ini menganggap bahwa Ezra 4:12 hanya merupakan fitnahan dari musuh- musuh Ezra).

Dalam ayat yang ke 6, merupakan ungkapan hati Nehemia kepada Allah, sepertihalnya Ezra, Nehemia juga mengakui bahwa dia dan keluarganya telah menganbil bagia dalam dosa seluruh umat Israel. Kata dengarkanlah yang memiliki kata dasar Dengar dalam bahasa Ibrani menggunakan kata shama. Dalam bahasa Inggris di terjemahkan to hear, listen to, obey, to hear with attention or interest, yang 
artinya mendengarkan dengan penuh perhatian. Nehemia memohon supaya Allah mendengar, mendengarkan dengan penuh perhatian, doanya dan menjawab apa yang dimohonkan oleh Nehemia untuk bangsa itu. Ini merupakan sebuah permohonan yang diungkapkan dengan sangat merendahkan diri dan sangat memohon kepada Allah. Doa yang di panjatkan kepada Allah dengan kesungguhan hati, telah mampu mengubah hati seorang raja besar yang berkuasa untuk melakukan hal yang secara manusia tidak mungkin, yakni mengijinkan Nehemia untuk membangun tembok Yerusalem.

Saat mendengar berita yang buruk Nehemia langsung melakukan sebuah tindakan yang tepat yakni datang kepada Allah dengan berdoa. Seorang pemimpin yang bijaksana adalah orang yang suka berdoa. Seorang pemimpin yang bijaksana akan berlutut dalam penyembahan yang penuh doa dan kerendahan hati lalu naik ke suatu tingkatan yang baru dalam hal hidup kudus dan benar. Bangsa Israel memiliki pedoman hidup yang merupakan suatu kebenaran yang berasal dari Allah. Dan mereka akan terus berusaha untuk terus mengajarkan kepada anak cucu mereka karena hal tersebut merupakan Perintah Allah. Jika bangsa Israel memiliki pedoman hidup yang berasal Dari Allah, yang terus diajarkan oleh para pendahulu mereka, maka masyarakat Jawa pada umumnya senang berbicara mengenai falsafah yang menjadi pedoman hidup. Orang Jawa bukan hanya senang membicarakannya namun juga berusaha untuk terus mengajarkannya kepada Anak cucu mereka.

Pemimpin adalah seorang yang menjadi public figure bagi semua orang dimana ia memimpin. Kata cakap dalam kamus besar bahasa Indonesia artinya adalah sanggup melakukan sesuatu, mampu, dapat, pandai, mempunyai kemampuan mengerjakan segala sesuatu.85 Bukan hanya itu namun ia juga seorang pekerja keras, mengerti kebutuhan orang-orang yang dipimpinnya dan selalu tepat waktu. Kecakapan seorang pemimpin dapat membangun semangat juang dan motivasi orang di sekelilingnya, seorang pemimpin harus mengetahui bagaimana cara melaksanakan pekerjaannya. Karena itu haruslah seorang pemimpin adalah orang yang sudah terlebih dahulu memahami apa yang menjadi sasarannya. Dalam ayat sebelumnya yakni ayat 3, yang merupakan jawaban dari pertanyaan dalam hati Nehemia. Ketika Nehemia mendengar ia dapat melihat dan merasakan Situasi Yerusalem, ia dapat melihat kota dan isinya. Ia melihat tembok yang hancur dan emosinya tersentuh. Berdasarkan hal tersebut dapat di lihat bahwa Visi Nehemia mulai menangkap perspektif pergumulan yang menggerakan dirinya.

Ada empat faktor yang penting yang perlu penulis ungkapkan karena sangat perlu untuk dimiliki oleh seorang pemimpin yang cakap, empat hal tersebut adalah:

- Seorang pemimpin harus mengetahui dan mengenal dengan jelas kebutuhan yang dihadapi. Saat mendengar berita, Nehemia tidak tinggal dalam mimpi namun ia memberikan perhatiannya. Dia menanyakan bagaimana keadaan orang orang buangan yang sudah kembali ke Yerusalem. Dan saat ia tahu bahwa mereka ada dalam kesusahan besar, maka Nehemia mendengarkan apa yang mereka katakan. Mengenalkebutuhan merupakan konsep permulaaan yang diperlukan oleh seorang pemimpin. Semua orang akan merasa senang jika ada orang lain yang mengerti kebutuhannya. Setelah melihat kebutuhan Nehemia merasakan adanya kebutuhan. Selanjutnya secara terencana ia membuka hati dan menaruh kebutuhan itu di dalam hatinya. 
- Seorang pemimpin harus mengerti kebutuhan yang terutama. Nehemia bukan hanya mendengar masalah-masalah yang dilaporkan tetapi Nehemia duduk dan memahami masalah-masalah tersebut. Nehemia dipanggil untuk membangun tembok, dan apa yang diungkapkan oleh Nehemia menunjukan bahwa ia seorang yang berbelas kasihan. Seorang pemimpin harus memiliki perhatian dan belas kasihan. Perhatian dan belas kasihan akan kelihatan dari cara seseorang menanggapi suatu masalah yang dihadapi.

- Pemimpin harus sungguh-sungguh jika menghadapi masalah yang pertamatama dilakukan adalah datang kepada Allah untuk meminta petunjuk atau hikmat Tuhan. Dalam ayat 5 Nehemia berkata "Ya Tuhan Allah semesta langit, Allah yang Maha besar dan dasyat yang berpegang pada perjanjian dan kasih setia-Nya terhadap orang yang kasih kepada-Nya dan tetap mengikuti perintahperintah-Nya," hal tersebut menunjukan bahwa Nehemia tahu bahwa ia tidak menghadap manusia tetapi dia menghadap Allah yang empunya langit. Karena Nehemia tahu bahwa raja bukanlah apa-apa jika dibandingkan dengan Allah. Sekalipun Nehemia dapat menghadap raja dengan permasalahan yang dihadapi, namun ia tidak memilih melakukan hal tersebut.

- Pemimpin juga harus berusaha menyediakan untuk memenuhi kebutuhannya sendiri. " biarlah hamba-Mu berhasil mendapat belaskasihan dari orang ini " Nehemia menyadari kebutuhannya dengan jelas, Nehemia melibatkan diri di dalanmya. Dia membawa persoalannya kepada Allah kemudian iamenyediakan diri/siap untuk memenuhi kebutuhan tersebut, jika itu yang dikehendaki Allah.

\section{Perjanjian Baru 1 Korintus 4:16; 11:1}

Di dalam suratnya kepada jemaat Korintus yang pertama, pada pasal 4:16 Paulus menuliskan supaya mereka mengikuti teladan Paulus. "Sebab itu aku menasihatkan kamu: turutilah teladanku!" kata turutilahdalam bahasa aslinya menggunakan kata mimhtai, (mimhtai)dari kata ' $\mathrm{m}$ (mimhthj) artinya mengikuti atau menyusul, sedangkan kata teladan dalam bahasa aslinga menggunakan kata' (gi,nesqe) dari kata' (gi,nomai)yang artinya adalah: perbuatan yang patut di tiru.

Pada pasal 11:1 Paulus mengajak agar jemaat Korintus menjadi Pengukutnya sama seperti dia telahmenjadi pengikut Kristus."Jadilah pengikutku, sama seperti aku juga telah menjadi pengikut Kristus". Kata pengikutku dalam bahasa aslinya memakai kata mimhtai, yang diartikan to the use of a model for exemplary living, Yang dapat diartikan mengikuti, dengan melihat contoh yang telah Paulus lakukan.

Menjadi pemimpin bukanlah hanya sebagai sebuah jabatan namun lebih dari itu terpenting adalah fungsi sang pemimpin dalam tugasnya. Yang dimaksud di sini adalah pemimpin dalam segala hal yang meliputi, gereja, sekolah keluarga dan lainnya. Pemimpin Kristen adalah pemimpin model yang harus menjadi teladan.

Pemimpin Kristen adalah pemimpin rohani yang harus memperhatikan kualitas hidup rohani sebagai seorang pelayan Tuhan. la harus memiliki integritas rohani yang dalam dan kuat yang diwujudkannya dengan setia dalamketaatannya kepada Allah dan FirmanNya. la harus berdisiplin tinggi dan menguasai diri dalam segala sisi hidup sehingga ia dapat membuktikan diri sebagai model hidup yang layak dicontoh. Rasul Paulus menasehati jemaat Korintus agar hidup sesuai dengan teladan yang telah Paulus berikan kepada Mereka. Paulus bukan hanya menasehai jemaat Korintus 
namun kepada jemaat Filipi juga dia memberikan nasehat yang sama yaitu supaya mereka hidup sesuai dengan teladan Paulus.

Selain keteladanan dalam hal rohani, seorang pemimpin Kristen juga harus menjadi teladan dalam berhubungan atau berelasi dengan orang lain. Harus dapat menjadi teladan dalam hal kerja, sehingga bawahan tidak hanya mendapat perintah saja, namun bawahan dapat melihat secara nyata bagaimana cara kerja yang baik. Dan yang paling penting adalah seorang pemimpin harus bersikap tegas (Matius 25:1430).

Yakob Tomatala, dalam bukunya yang berjudul Kepemimpinan yang Dinamis mengatakan "Pemimpin Kristen adalah pemimpin yang pragmatis serta produktif yang menghasilkan dalam kepemimpinannya." Sekalipun pemimpin rohani ia juga harus memiliki orientasi pada hasil atau sukses, dengan menerapkan usaha yang bersesuaian dengan kebenaran Alkitab. Perlu di ingat bahwa dunia memandang orang Kristen sebagai contoh yang nyata dari kebenaran dan kuasa Injil. Orang yang belum percaya akan memandang pemimpin Kristen dan orang Kristen sebagai contoh ideal yang selalu dilihat.

Falsafah yang di miliki oleh orang Jawa yang bermakna bahwa seorang pemimpin harus dapat menjadi teladan, harus mampu membangun motivasi, dan harus mampu memberikan kekuatan. Jika di lihat pada masa kini maka hal itu bukan hanya merupakan falsafah orang jawa pada kususnya namun seakiuran sudah menjadi falsafah nasional. Di semua bidang pendidikan tentu sudah mengenal falsafah jawa tersebut. Apalagi salahsatu falsafah yang berbunyi Tut Wuri Handayani, menjadi logo dalam pendidikan di Indonesia. Walsafah Jawa tersebut baik dan jika di terapkan pasti akan terjadi hubungan yang harmonis antara guru dan murid maupun pemimpin dan bawahan. Tetapi sebagai orang Kristen Jawa yang sudah mengetahui kebenaran Alkitab tentunya yang menjadi tolok ukur dalam melakukan segala sesuatu adalah Alkitab.

Tokoh dalam Perjanjian Lama yaitu Nehemia telah memberikan teladan seorang pemimpin secara rohani. la telah menjadi pemimpin yang menjadi teladan, membangun motivasi para pengikutnya serta senantiasa memberikan dorongan kepada mereka saat mereka lemah dan putus asa, sampai akhirnya tembok Yerusalem di bangun kembali. Tokoh dalam Perjanjian Baru yang tidak kalah menarik dari Nehemia adalah Paulus. Beliau adalah tokoh yang sangat berjasa bagi penyebaran kekristenan mula-mula. Mereka bukan hanya melakukan pelayanan seorang diri, namun ia mendidik, membina orang lain agar dapat melayani bersama. Bukan hanya mengajar namun ia juga memberikan diri sebagai teladan bagi orang lain.

Orang Kristen Jawa memahami Falsafah “ Ing Ngarsa Sung Tuladha, Ing Madya Mangun Karsa, Tut Wuri Handayani " dalam perspektif pemikiran mereka sebagai orang Jawa, namun kebenaran Alkitab jauh memberikan pengajaran yang lebih dari sekedar falsafah tersebut. Karena falsafah tersebut hanyalah pemikiran manusia, namun Alkitabadalah Firman Allah. Karena di dalamnya nyata kebenaran Allah dan didalamnya Allah menyatakan diri-Nya. 


\section{Dasar Alkitab Terhadap Tinjauan Falsafah Jawa “Ing Ngarsa Sung Tuladha, Ing Madya Mangun Karsa, Tut Wuri Handayani"}

Alkitab adalah sumber kebenaran yang diyakini oleh orang Kristen, dari Firman Tuhan inilah orang Kristen dapat bertumbuh dan mengenal Tuhan Yesus yang telah menebus dosa manusia. Karena itu penulis mendasarkan dasar tinjauan ini dari Alkitab, adapun dasar Alkitab yang penulis ambil adalah dari Perjanjian Lama dan dari Perjanjian Baru. Dari Perjanjian Lama penulis mengambil dari Nehemia 1:4 dan Nehemia 1:6, sedangkan dari Perjanjian Baru penulis mengambil dari 1 Korintus 4:16 dan 1 Korintus 11: 1.

Dalam Nehemia 1:4 menjelaskan mengenai keteladanan Nehemia dalam memimpin pembangunan tembok Yerusalem. Dalam Nehemia 1:4-10, di sini dijelaskan mengenai Nehemia, seorang pemimpin yang bukan hanya memerintah anak buahnya namun ia juga memberi teladan, membangun motivasi orang-porang yang yang terlibat dalam proyek tersebut dan memberikan dorongan bagi mereka. Selain itu Nehemia juga memperhatikan semua kebutuhan orang-orang yang dipimpinnya. Selain Nehemia contoh pemimpin yang menjadi teladan, memberi motivasi dan kekuatan pada pengikutnya yang hidup dalam zaman Perjanjian Lama adalah: Musa, Yosua, Daud, dan Salomo mereka semua merupakan pemimpin yang kuat pada masanya. Dan merupakan orang-orang yang berpengaruh besar bagi orang-orang yang mereka pimpin.

Dalam 1 Korintus 4:16 dan 1 Korintus 11: 1, menjelaskan mengenai kepemimpinan Paulus dalam memimpin jemaat yang ia layani, maupun orang-orang yang membantu pelayanannya. Dalam 1 Korintus 4:16, Paulus menjelaskan supaya mereka mengikuti teladan Paulus. Yang Paulus maksudkan dengan mereka yaitu orang- orang penerima surat kiriman, yakni orang-orang Korintus yang pada waktu itu yang merupakan jemaat hasil penginjilan Paulus. Paulus menasihatkan mereka supaya hidup meneladani sikap dan tindakan Paulus yang patut dicontoh. Paulus adalah seorang pemimpin Kristen pada masanya yang merupakan pemimpin rohani yang kuat dan militan. Selain seorang pemimpin Paulus juga berhasil memuridkan orang lain untuk dapat melakukan hal yang serupa dengan dirinya.

Paulus seorang pemimpin Kristen yang memperhatikan kualitas hidup rohani sebagai pelayan Tuhan. Karena itu layaklah Paulus memberi nasihat pada mereka untuk mengikuti teladannya, karena ia bukan hanya menyuruh saja namun ia telah terlebih dahulu diuji oleh semuanya itu. Paulus telah menggunakan karunia Rohani yang Allah berikan untuk melayani orang-orang yang belum percaya dan mencapai tujuan yang Allah berikan, yaitu Allah di muliakan karena orang-orang yang belum percaya menjadi percaya kepada Allah. Dan Allah dimuliakan saat orang-orang percaya kembali kepada Allah dan menyembah Allah yang benar.

Rasul Paulus mengerti Filsafat, namun ia juga memahami Firman Tuhan, sehingga filsafat yang ia ketahui, ia pakai untuk sarana penginjilan. Seharusnya orang Kristen Jawa melakukan hal yang serupa dengan Nehemia, yang tetap percaya dan setia kepada Allah yang ia percaya, karena Nehemia mengerti Tuhan dan FirmanNya, dan Nehemia juga mengetahui siapa allah yang disembah oleh bangsa dimana ia tinggal. Lingkungan sekitar tidak membuatnya meninggalkan Tuhan. Hal serupa dilakukan Paulus, ia mengetahui filsafat namun ia tidak terpengaruh olehnya, justru menggunakan filsafat sebagai alat berteologi. Mereka juga seharusnya demikian yaitu mengerti perbedaan antara Firman Tuhan dengan falsafah, sehingga pada akhirnya 
jemaat menerapkan Firman Tuhan dalam hidupnya dan mengerti falsafah yang harus diterapkan.

Nehemia adalah contoh umat Allah yang mengerti identitasnya. la tahu bahwa dirinya adalah umat pilihan Allah, sehingga selama ia ada dalam pembuangan tetap beribadah dengan Tuhan Allah Israel. Karena Nehemia mengetahui siapa dirinya maka ia rela mau melaksanakan perintah Tuhan kepadanya sekalipun ia harus meninggalkan kehidupan nyaman di istana raja. Bahkan pada saat menghadapi tantangan waktu pembangunan, Nehemia bersedia dan terus mendorong timnya untuk terus membangun tembok Yerusalem.

Adapun tujuan dari tinjauan terhdap Falsafah Jawa "IngNgarsa Sung Tuladha, Ing Madya Mangun Karsa, Tut Wuri Handayani”adalah sebagai berikut:

\section{Supaya Jemaat Memiliki Pemahaman Kebenaran Berdasarkan Kebenaran Alkitab.}

Falsafah yang erat dengan kehidupan orang Jawa terus diterapkan oleh orang Kristen Jawa, sekalupun sebagian besar mereka tidak menyadarinya. Yang menjadi salah satu tujuan penulis melakukan injauan Alkitabiah terhadap falsafah Jawa adalah supaya jemaat mengerti tinjauan Alkitabiah terhadap falsafah Jawa "Ing Ngarsa Sung Tuladha, Ing Madya Mangun Karsa, Tut Wuri Handayani”. Supaya jemaat memiliki pemahaman kebenaran berdasarkan kebenaran Alkitab, bukan falsafah. Jika jemaat mendasarkan kebenaran pada falsafah dan bukan Alkitab maka mereka tidak akan menjadi orang Kristen yang menular. Orang Kristen dan orang yang belum mengenal Kristus haruslah memiliki perbedaan yang dapat dilihat melalui sikap hidupnya. Karena akan ada upah bagi orang Kristen yang menularkan pengaruhnya bagi orang yang belum percaya.

\section{Jemaat Mengerti perbedaan antara Falsafah Jawa dengan Kebenaran Alkitab.}

Tujuan akhir penulis melakukan tinjauan ini adalah supaya pada akhirnya jemaat tahu manakah yang akan mereka terapkan. Falsafah Jawa yang secara turun temurun telah mereka terapkan atau Firman Tuhan yang memiliki kebenaran sejati yang dapat mengubah hidup manusia yang akan jemaat terapkan. Sekalipun falsafah memiliki nilai kebenaran, namun falsafah bukanlah Firman Tuhan. Falsafah adalah hasil pikiran bijaksana manusia. Sedangkan Firman Tuhan adalah kebenaran yang berasal dari Tuhan yang kekal dan berkuasa. Falsafah hanya sebagai alat untuk menyederkanakan sebuah doktrin supaya manusia lebih mengerti. Bukan untuk menerapkan kebenaran falsafah.

\section{Supaya Jemaat Menerapkan Kebenaran Alkitab di dalam hidup mereka}

Dalam Kolose 2:8, tertulis bahwa "hati-hatilah supaya jangan ada yang menahan kamu dengan Filsafatnya yang kosong dan palsu menurut ajaran turun temurun dan roh- roh dunia, tetapi tidak menurut Kristus". Ada orang Kristen yang mau mempelajari falsafah, namun ada juga orang Kristen Jawa yang tidak mau mempelajarinya, atau bahkan anti dengan falsafah karena menganggap bahwa falsafah bukanlah kebenaran yang berasal dari Tuhan, namun hanya hikmat manusia belaka.

Kehidupan orang Jawa erat kaitannya dengan falsafah, orang Jawa terkenal dengan sopan santun dan keramahannya. Orang Jawa Juga memiliki banyak 
kelebihan, yaitu mereka mudah bergaul dengan orang lain, karena mereka luwes. Pada umumnya orang Jawa tetap mempertahankan tradisi kebudayaannya. Salah satu yang sampai saat ini masih diterapkan adalah falsafah. Falsafah Jawa yang memiliki nilai kehidupan yang sampai sekarang diterapkan oleh orang Kristen Jawa, hanyalah merupakan ide dari manusia. Hal tersebut adalah baik dan sebagai upaya untuk dapat memahami kebenaran Alkitab. Namun hal tersebut akan menjadi salah jika jemaat menerapkan falsafah bukan kebenaran Alkitab. Karena sumber kebenaran yang berasal dari Allah adalah Alkitab, bukan falsafah maupun pikiran manusia. Hal yang paling penting yang harus diterapkan dan harus menjadi tolok ukur bagi orang Kristen untuk hidupnya adalah Firman Tuhan. Karena Firman Tuhan dapat mengubah hidup manusia, sehingga manusia memiliki hidup yang lebih baik.

\section{Kesimpulan}

Kehidupan orang Jawa erat dengan Falsafah dan mereka merasa bangga jika dapat mempertahankan nilai-nilai luhur dari para pendahulu mereka. Orang Jawa sampai saat ini masih menerapkan falsafah Jawa, bukan hanya orang Jawa pada umumnya namun, orang Kristen juga menerapkannya. Seharusnya orang Kristen Jawa tidak mempersamakan Firman Tuhan dengan Falsafah Jawa. Orang Kristen Jawa Hidup dalam tradisi hanya dengan bentuk lain. Falsafah Jawa pada dasarnya hendak menekankan keteladanan seorang pemimpin atau seorang pemimpin. Bahwa segala keteladanan pemimpin. Oleh karena sebagai orang Jawa prinsip guyub atau kebersamaan maka apa yang dikatakan pimpinannya harus diikuti. Dalam Alkitab Perjanjian Lama maupun Perjanjian Baru, sudah dikisahkan tokoh- tokoh pemimpin yang menjadi teladan, membangun motivasi maupun memberikan kekuatan kepada orang-orang yang dipimpinnya. Nehemia dan paulus yang penulis contohkan sebagai seorang pemimpin yang menjadi "Ing Ngarsa Sung Tuladha, Ing Madya Mangun Karsa, Tut Wuri Handayani”. Dan yang membuat mereka dapat menjadi pemimpin yang seperti itu bukan karena mereka menerapkan falsafah Jawa namun karena mereka hidup takut Tuhan.

Firman Tuhan dan falsafah memiliki perbedaan, jika falsafah adalah hikmat manusia yang pengajarannya sampai pada moralitas seseorang namun Alkitab atau Furman Tuhan adalah hikmat Tuhan yang dapat mengubah kehidupan seseorang. Di dalam Firman Tuhanlah manusia dapat menbgerti bahwa Allah mengasihi dan menyediakan anugerah keselamatan bagi yang percaya kepadaNya. Sebagai orang Kristen yang sejati seharusnya hidup dalam Firman Tuhan dan tidak mempersamakan Firman Tuhan dengan Falsafah Karena keduanya berbeda. 


\section{Kepustakaan}

Ali, Lukman, $1991 \quad$ Kamus Besar Bahasa Indonesia, Jakarta: Balai Pustaka

Barna, George, $2009 \quad$ Leaders On Leadership, Malang : Gandum Mas

Chambers, Oswald, $2001 \quad$ Karya Allah, Batam: Gospel Press

Chan, Edmund, 2014 A Certain Kind, Singapore: Covenant Evangelical Free Church

Clinton, Richard \& Paul Leaven Worth, 2004 Memulai Dengan Baik, Jakarta: METANOIA

Darmaputra, Eka, 2005 Kepemimpinan Dalam perspektif Alkitab, Yogyakarta : Kairos Books

Donahue, Bil dan Greg Browman, 2010 Membina Pembimbing Kelompok Kecil Untuk Mengubah Hidup, Yogyakarta: GLORIA GRAFA

Eims, Leroy, 198112 ciri Kepemimpinan yang Efektif, Bandung: Yayasan Kalam Hidup Goleman, Daniel, 2006 Kepemimpinan Berdasarkan Kecerdasan Emosi, Jakarta: Gramedia Hadianto, Sum, 2015 Berakar Di Dalam Kristus, Yogyakarta : Yayasan Gloria Hardjowirogo, Marbangun, $1994 \quad$ Manusia Jawa, Jakarta : Cv Haji Masagung

Hybels, Bill \& Mark Mittelberg, $2000 \quad$ Menjadi Orang Kristen Yang Menular, Yogyakarta : Yayasan ANDI

Manafe, Ferdinan S, 2014 Teologi Ibadah, Batu : Literatur YPPII Batu

Maxwell, John C., $2001 \quad$ Go For Gold, Jakarta : Immanuel

Mirnawati, 2003 Kumpulan Pahlawan Indonesia Terlengkap, Jakarta Timur : CIF Penebar Swadaya

Mulder, Niel, 1996 Pribadi Dan Masyarakat Di Jawa, Jakarta : Pustaka Sinar Harapan

Oh Robert, 2005 The Prayer Driven Life, Yogyakarta : Penerbit Andi

Owen, John Joseph, 1993

Analitycal Key to The Old Testament, Michigan: United States Of America

Packer, J.I., $1991 \quad$ Kristen Sejati, Jakarta : Lembaga Reformed Injili Indonesia Pfeiffer, Charles F dan Everett F Harrison, 2007 The Wyclife Bible Commentary, Malang: Gandum Mas 
Rim, Jeremia,

1995 Iman Yang Hidup Dan Berkuasa, Yogyakarta : Yayasan Andi

Ronda, Daniel, $2011 \quad$ Leadership Wisdom, Bandung : Yayasan Kalam Hidup

Sirait, Sunandar, 2015 Berakar Di Dalam Kristus, Yogyakarta : Yayasan Gloria

Sitourus, Forida Gustiana, 2015 Berakar Dalam Kristus, Yogyakarta : Yayasan Gloria

Soedarmadji Boy \& Hartono,

2012

Psikologi Konseling, Jakarta: KENCANA

Solmon, Robert M, 2016

Kitab 1 dan 2 Timotius, Jakarta: Duta Harapan Dunia

Stedman, Ray C, $2014 \quad$ Petualangan Menjelajah Perjanjian Lama, Jakarta: LAl

Swindoll, Charles R, $\mathrm{Tt}$

Kepemimpinan Kristen yang Berhasil, Surabaya: YAKIN

Tomatala, Yakob, 1997

Kepemimpinan YangDinamis, Malang: Gandum Mas

Warren, Rick, $2015 \quad$ Untuk Apa Aku Ada Di Dunia Ini, Jakarta : Imanuel

Zuriah, Nurul, 2008 Pendidikan Moral Dan Budi Pekerti Dalam Perspektif Perubahan, Jakarta: Bumi aksara

\section{Internet}

- $\quad$ www.golgothaministry.com, diakses 2 April 2018

- www.wordpress.com, diakses 11 Februari2018 